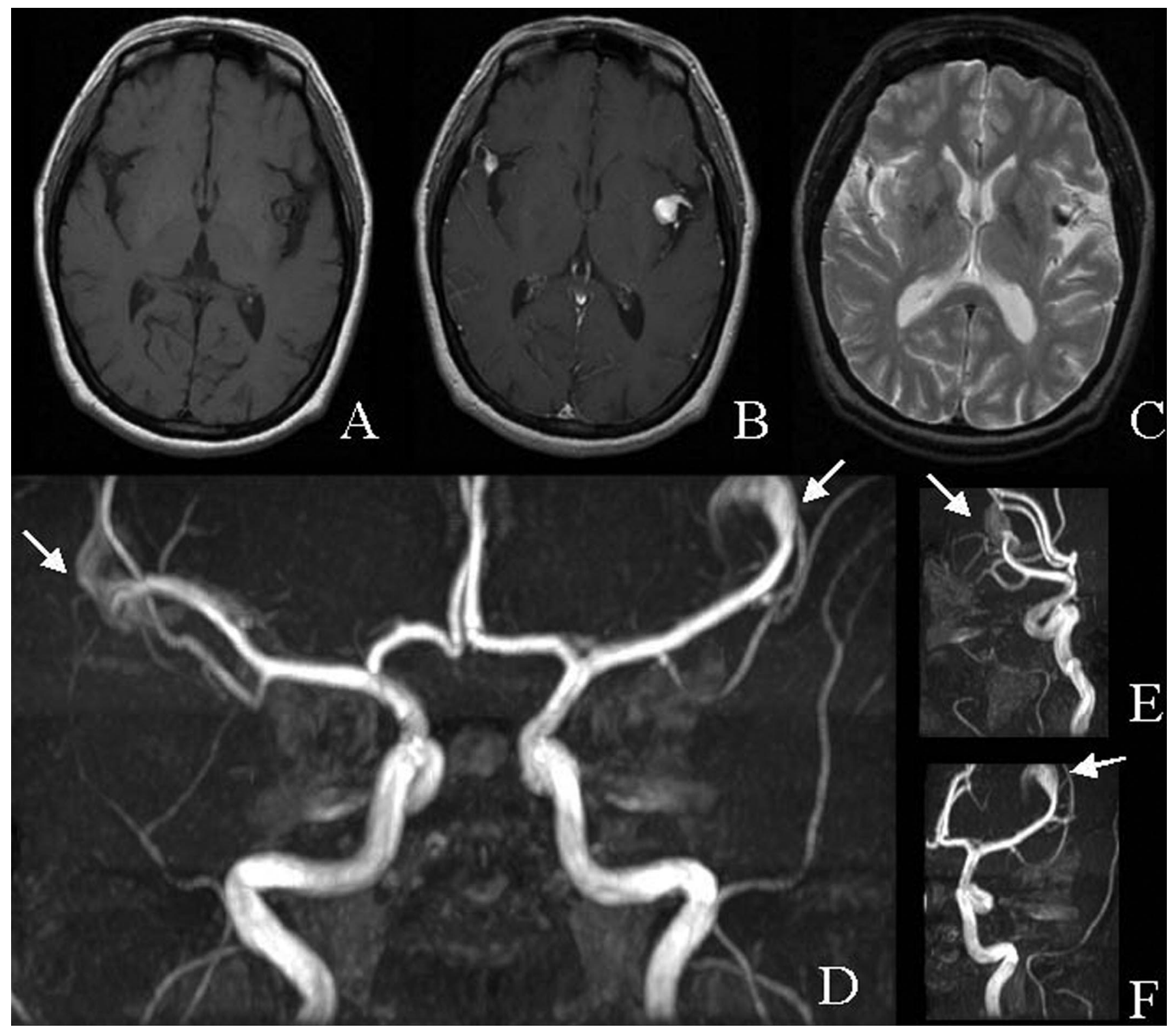

Figure. T1 pre-(A), T1 post-Gadolinium (B), and T2 (C) MRI images showing enhancing structures in the area of the left and right middle cerebral arteries. Magnetic resonance angiography images of the Circle of Willis (D), left (E), and right (F) middle cerebral arteries show that these structures represent fusiform dilatation of these arteries (arrows).

\section{Multiple stable fusiform intracranial aneurysms following atrial myxoma}

S. Andrew Josephson, $M D$; and S. Claiborne Johnston, $M D, P h D$, San Francisco, CA

A 33-year-old woman presented in 1989 with multiple embolic strokes from a left atrial myxoma. Eight years later, magnetic resonance angiography showed multiple fusiform aneurysms that

Address all correspondence and reprint requests to Dr. S. Claiborne Johnston, Department of Neurology, 505 Parnassus Avenue, M-798, San Francisco, CA, 94143-0114; e-mail: Clay.Johnston@ucsfmedctr.org have been stable on yearly imaging studies, and the patient currently remains asymptomatic (figure, A through F).

Fusiform aneurysms have been reported as a neurologic complication of atrial myxoma. ${ }^{1,2}$ The natural history of these aneurysms is unknown. Given the invasion of the vascular intima by myxoma tumor cells, these aneurysms may be flimsy and endovascular or surgical treatments may be particularly risky. The stability of these aneurysms in our patient over a 7 to 15 year period argues for conservative management.

1. Yilmaz MB, Akin Y, Guray U, Kisacik HL, Korkmaz S. Late recurrence of left atrial myxoma with multiple intracranial aneurysms. Int J Cardiol 2003;87:303-305.

2. Nucifora PG, Dillon WP. MR diagnosis of myxomatous aneurysms: report of two cases. AJNR Am J Neuroradiol 2001;22:1349-1352. 


\section{Neurology}

\section{Multiple stable fusiform intracranial aneurysms following atrial myxoma}

S. Andrew Josephson and S. Claiborne Johnston

Neurology 2005;64;526

DOI 10.1212/01.WNL.0000145838.61057.E8

\section{This information is current as of February 7, 2005}

\section{Updated Information \&} Services

Supplementary Material

References

Subspecialty Collections

Permissions \& Licensing

Reprints including high resolution figures, can be found at: http://n.neurology.org/content/64/3/526.full

Supplementary material can be found at: http://n.neurology.org/content/suppl/2012/04/16/64.3.526.DC1

This article cites 2 articles, 1 of which you can access for free at: http://n.neurology.org/content/64/3/526.full\#ref-list-1

This article, along with others on similar topics, appears in the following collection(s):

All Cerebrovascular disease/Stroke

http://n.neurology.org/cgi/collection/all_cerebrovascular_disease_strok e

Cardiac

http://n.neurology.org/cgi/collection/cardiac

MRI

http://n.neurology.org/cgi/collection/mri

Subarachnoid hemorrhage

http://n.neurology.org/cgi/collection/subarachnoid_hemorrhage

Information about reproducing this article in parts (figures,tables) or in its entirety can be found online at:

http://www.neurology.org/about/about_the_journal\#permissions

Information about ordering reprints can be found online:

http://n.neurology.org/subscribers/advertise

Neurology ${ }^{\circledR}$ is the official journal of the American Academy of Neurology. Published continuously since 1951, it is now a weekly with 48 issues per year. Copyright . All rights reserved. Print ISSN: 0028-3878. Online ISSN: 1526-632X.

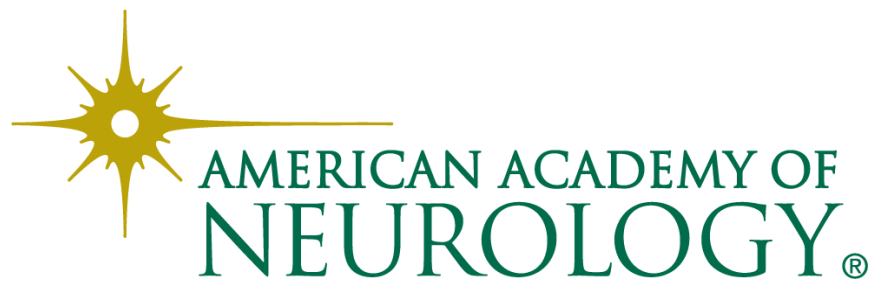

